\title{
СТРАТЕГІЧНІ ОСНОВИ ІНВЕСТИЦІЙНОГО ЗАБЕЗПЕЧЕННЯ ТЕРИТОРІАЛЬНИХ ГРОМАД
}

В процесі децентралізаційної реформи об'єднані територіальні громади сьогодні вступають в новий етап свого розвитку. Вони отримали повноваження, інвестиційні ресурси, є відповідальними перед своїми жителями за формування комфортного й безпечного середовища проживання. Задля цього потрібен прогнозований i вмотивований розвиток громад. Необхідною $є$ нині базова динамічна конкурентна стратегія розвитку територіальних громад зі урахуванням інвестиційної складової, яка б передбачала формування конкурентних переваг громади шляхом мінімізації впливу на нівелювання слабких сторін за допомогою можливостей, які зараз виникають в процесі децентралізації. При цьому громада повинна максимально використовувати свої сильні сторони. Сьогодні в Україні сформовано нормативно-законодавчу основу задля регіонального розвитку, що в цілому відповідає кращим європейським стандартам. Нині розроблено державну стратегію регіонального розвитку, яка подібна за змістом і структурою до аналогічних документів країн-членів Європейського Союзу. На основі проведеного дослідження на прикладі Млинівської ОТГ, запропоновано план стратегічного розвитку Млинівської ОТГ, що дозволить реалізувати принципово новий підхід до планування, інвестування й управління економічного розвитку. Відмінності такого плану полягають у відображенні й реалізації інтересів територіальної громади, системний підхід до розв'язання проблем розвитку. Стратегічний план розвитку громади містять заходи щодо коротко-, середньо- та довгострокового інвестування. Унаслідок реформи децентралізації місцеві громади здобули кращі можливості щодо розвитку своїх територій, створення сучасної медичної, освітньої, транспортної, житлово-комунальної інфраструктури, а також перспективи поліпшити життя громадян у кожному населеному пункті.

Ключові слова: територіальна громада; держава; інвестиції; природні ресурси; стратегія розвитку; сталий розвиток; стратегія.

Постановка проблеми. В останні кілька десятиліть спостерігається тенденція занепаду традиційного села. 
Найімовірнішою причиною цього є низька якість життя у сільській місцевості, що, поряд із низьким рівнем доходів населення й обмеженими економічними можливостями, характеризується також низьким рівнем якості й доступності різноманітних послуг, важливих для повсякденного життя - культурних, освітніх, дозвільних, охорони здоров'я. В цих умовах децентралізаційна реформа стала істотним інструментом притоку інвестицій у територіальні громади.

Аналіз останніх досліджень i публікацій. Питання стратегічного інвестиційного забезпечення територіальних громад досіджувалося С. Білою, В. Бабаєвим, 3. Варналієм, В. Воротіним, В. Куйбідою, С. Рогачовим та іншими. Серед дослідників інвестиційної привабливості територій потрібно виокремити Г. Вєтрова, В. Мамонову, О. Карого, О. Лук'янченка, О.Широкова, С. Юркову. Практичним і теоретичні аспектам функціонування механізмів державного управління у сфері стратегічного планування розвитку територій надавали перевагу в своїх дослідженнях O. Берданова, В. Вакуленко, І. Дунаєва, М. Латиніна, І. Санжаровський, В. Тертичка [1-4]. Проте, незважаючи на різноплановість проведених досліджень, наявний практичний досвід, на сьогодні недостатньо вивченими $\epsilon$ перспективи подальшого вдосконалення механізмів державного управління у сфері стратегічного планування територій 3 урахуванням інвестиційної складової під час здійснення процесів децентралізації державної влади. Все це зумовило актуальність даного дослідження.

Постановка завдання. Метою даної роботи $\epsilon$ дослідження стратегічних основ розвитку об'єднаних територіальних громад 3 урахуванням інвестиційної складової в умовах європейської інтеграції. Дослідження проведено на прикладі Млинівської ОТГ. У роботі розроблено практичні рекомендації щодо вдосконалення стратегічного інвестиційного планування територіальних громад в Україні.

Виклад основного матеріалу. Відомо, Європейський Союз загалом приділяє дуже велику увагу регіональному розвитку й створенню підґрунтя для єдності європейських регіонів, формування солідарної цілісної Європи. Саме таке завдання поставили собі уряди європейських країн, органи управління регіонів, органи управління великих муніципалітетів. Адже навіть у великих містах $є$ райони, які надто вирізняються чисельністю і структурою населення, рівнем доходів, рівнем злочинності, станом довкілля, інвестиційним кліматом. Усі держави, особливо члени Європейського Союзу, прагнуть втілювати свою регіональну політику таким чином, аби 
використати міжрегіональні відмінності як можливості й стимулювання розвитку і намагається не допустити їх перетворення на проблеми національної єдності й безпеки [5].

Нині стратегічне інвестиційне планування соціальноекономічного розвитку територій займає вагоме місце у діяльності органів державної влади й місцевого самоврядування України. До недавнього часу в Україні існувало понад 12 тис. територіальних громад, при цьому половина з них налічували чисельність жителів менше ніж 3 тис. осіб, серед яких у 4809 громадах проживало менше як 1 тис. осіб, а у 1129 громадах - менше за 500 осіб. У переважної більшості зі територіальних громад не були утворені виконавчі органи відповідних сільських рад, відсутні бюджетні установи, комунальні підприємства тощо. Окрім цього, дотаційність 5419 бюджетів місцевого самоврядування становила понад 70\%, 483 територіальні громади на 90\% утримували за кошти державного бюджету [3].

Звісно, що все це викликало наявність таких проблем у сфері стратегічного інвестиційного планування розвитку територій, як:

- погіршення якості й доступності публічних послуг для жителів громад;

- невідповідність стратегії і тактики у сфері стратегічного планування територій реальним інтересам й потребам розвитку територіальної громади;

- відсутність відкритості чи прозорості у діяльності органів місцевого самоврядування і органів державної влади у сфері інвестування й стратегічного планування;

- погіршення інвестиційної привабливості територій, надмірна централізація повноважень органів виконавчої влади у сфері стратегічного планування [1-5].

Здійснення процесу децентралізації стало необхідною умовою подальшого збалансованого розвитку та ефективного функціонування територій. Децентралізація відкрила нові фінансові можливості для громад. Адже економічно міцна й фінансово стабільна держава $€$ базою задля зміцнення потужності територій і додатковим чинником для вирішення місцевих проблем: подолання надмірних міжрегіональних диспропорцій, депресивності територій, пошуку точок економічного зростання. Тобто територіальні громади нестимуть відповідальність за планування свого розвитку і бюджету, за економічний розвиток, залучення інвестицій і розвиток підприємництва. 
Встановлено, що розвиток стратегічного планування територій $\epsilon$ об'єктивною необхідністю і спричинений певними загальнодержавними, загальносвітовими й місцевими тенденціями в соціально-економічному й екологічному розвитку. Таке стратегічне планування, насамперед, надає суттєві переваги як для органів державної влади, так й для територіальної громади в цілому.

У ході узагальнення наявних концепцій, що повинні бути враховані в процесі створення й функціонування механізмів державного управління у сфері стратегічного планування $\epsilon$ концепції сталого розвитку; унікалізму; універсалізму; «громада підприємець», «громада - двірник» [4-7].

Узагальнення наукової літератури дозволило сформувати сутність стратегічного інвестиційного планування (СІП) як складну систему публічного управління стратегічного планування соціоеколого-економічного розвитку територій; діяльність органів державної влади, місцевого самоврядування й членів громад або їх представників щодо визначення основної мети та завдань розвитку окремої території; послідовність конкретних дій щодо розроблення стратегічних документів розвитку на регіональному й місцевому рівнях і залучення інвестиційних ресурсів задля створення нової додаткової вартості.

Встановлено, що задля розвитку стратегічного інвестиційного планування територій нині необхідно сформувати ефективні механізми державного управління: нормативно-правове, організаційне, економічне, інформаційне, соціальне та відповідне методологічне, методичне, ресурсне, інформаційне забезпечення даного процесу.

В результаті проведеної оцінки визначено основні проблеми методичного забезпечення СІП територій на регіональному й місцевому рівнях: відсутні єдині підходи у розробленні документів СІП на регіональному й місцевому рівнях з точки зору змісту таких документів, як джерела інформації, необхідної для аналізу й оцінок, відсутність єдиних методичних підходів до розробки документів СІП, неузгодженість стратегічних документів різного рівня.

Виділено основні етапи щодо розвитку нормативно-правового механізму СІП. Визначені особливості сучасного етапу розвитку нормативно-правового механізму СІП: розвиток конкуренції між територіями, за інвесторами, за отриманням коштів від державного й регіональних бюджетів, ґрантів; системи публічного управління; розвиток громадської активності членів громади та державноприватного партнерства. Нині основні відмінності у вітчизняному та 
закордонному підходах до СІП зумовлені відсутністю в Україні стабільної нормативно-правової, економічної основи такого планування. Як свідчить кращий закордонний досвід, який варто застосувати в Україні, потрібно формувати «полюси росту», інтегровані 3 регіональними й світовими ринками; надавати пріоритетний розвиток містам-лідерам і опорним містам; продукувати стратегії розвитку населених пунктів згідно їх значення в національній системі розселення; здійснювати розроблення інноваційних стратегій розвитку територій; укладати угоди між регіональними й місцевими органами влади, органами місцевого самоврядування.

Підвищення спроможності місцевого населення й установ і їх готовність взяти участь та надати підтримку у реалізації програми $€$ наступним важливим кроком, що сприятиме ефективному використанню сільськогосподарського, туристичного і підприємницького потенціалів всіх територіальних громад. Участь фермерів, сільськогосподарських підприємств й інших суб'єктів розвитку села $\epsilon$ істотною у досягненні успіху зі створення сільськогосподарських кооперативів. Проте існують певні ризики у реалізації програми:

- Неможливість встановлення необхідних партнерських відносин й отримання підтримки від зацікавлених сторін в населених пунктах, готових здійснювати реалізацію як конкретних проектів так й стратегії в цілому.

- Зниження інвестиційного рейтингу країни і регіону; зменшення обсягів чи взагалі скасування субвенції на розвиток інфраструктури територіальних громад;

- Нехтування сільськими територіями на користь селища старіння населення, низький рівень інвестицій, демографічний спад, міграція;

- Відсутність місцевих знань й управлінської спроможності щодо реалізації проектів і відсутність успіхів у мобілізації необхідних фінансових ресурсів;

- Нездатність налагодити сприятливі зв'язки між селом та містом, належний інвестиційний клімат, нераціональне використання природних ресурсів;

- Невчасне розв'язання інфраструктурних, екологічних, соціальних, освітніх та інших проблем сільського населення [5-7].

Важливим етапом формування стратегічного плану розвитку будь-якої території $€$ аналіз середовища. Звісно, це складний процес, який вимагає детального розкриття усіх процесів, які відбуваються у 
внутрішньому середовищі, оцінки факторів і встановлення зв'язку між ними, а також між сильними і слабкими сторонами функціонування території, можливостями і загрозами, які пов'язані із зовнішнім середовищем. У даній роботі проведено соціальноекономічний аналіз на прикладі Млинівської ОТГ, який стане основою розроблення ефективної стратегіï іï розвитку. При стратегічному плануванні середовище вивчається для того, аби визначити головні цілі розвитку й забезпечити успішне просування до визначених цілей, виробити стратегію взаємодії з елементами зовнішнього середовища, що забезпечить найбільш комфортне існування території.

Визначено інструменти державного управління задля формування ефективної стратегії розвитку ОТГ, окрім податкових надходжень, громади використовують матеріальну допомогу від держави на розвиток, тобто субвенції на соціально-економічний розвиток окремих територій, формування інфраструктури ОТГ, а також кошти Державного фонду регіонального розвитку та ін. Загалом на таку матеріальну допомогу з держбюджету 2019 року було витрачено понад 14,5 млрд грн. Кожна ОТГ щорічно має змогу отримувати кошти відразу за трьома інструментами розвитку: субвенція на формування інфраструктури ОТГ (отримують усі без винятку ОТГ), а кошти з двох інших інструментів розвитку отримають тільки розвинуті ОТГ. Зокрема, для отримання фінансування зі Державного фонду регіонального розвитку кожна ОТГ нині повинна мати фахівця зі складання й супроводу проектів та, відповідно, кошти для співфінансування таких проектів. У даній статті проаналізовано, які з цих інструментів державного управління залучає Млинівська ОТГ і виявлено, що Млинівська ОТГ активно використовує ці інструменти задля розвитку своєї ОТГ. Зокрема, лише в 2019 році з інфраструктурної субвенції Млинівська ОТГ реалізовує 15 проєктів на загальну суму 4,4 млн грн. Впродовж усього періоду функціонування цієї ОТГ було реалізовано 53 проєкти вартістю більше ніж 16 млн грн. Впродовж 2018-2019 років Млинівська ОТГ реалізувала 11 проєктів, загальною вартістю понад 3,5 млн грн за кошти субвенції 3 державного бюджету місцевим бюджетам на здійснення заходів щодо соціально-економічного розвитку окремих територій громади. Також Млинівська ОТГ $\epsilon$ постійною учасницею обласного конкурсу проєктів розвитку територіальних громад. За 3 роки громада реалізувала 3 проєкти на суму понад 470 млн грн [1-6]. 
Таблиця 1

Млинівська ОТГ у структурі територій вищої ланки

\begin{tabular}{|l|r|r|r|r|r|}
\hline \multicolumn{1}{|c|}{ Територія } & $\begin{array}{c}\text { Площа, } \\
\text { км²}\end{array}$ & $\begin{array}{c}\text { Площа у \% } \\
\text { до загальної } \\
\text { площі }\end{array}$ & $\begin{array}{c}\text { Населенняя } \\
\text { тис. осіб }\end{array}$ & $\begin{array}{c}\text { Населення у \% } \\
\text { до загальної } \\
\text { чисельності } \\
\text { населення }\end{array}$ & $\begin{array}{c}\text { Густота } \\
\text { населення, } \\
\text { осіб }\end{array}$ \\
\hline $\begin{array}{l}\text { Млинівська } \\
\text { громада }\end{array}$ & 345,7 & $36,6 / 0,2$ & 18,7 & $49,9 / 1,6$ & 54,1 \\
\hline $\begin{array}{l}\text { Млинівський } \\
\text { район }\end{array}$ & 945 & 4,7 & 37,5 & 3.2 & 39,7 \\
\hline $\begin{array}{l}\text { Рівненська } \\
\text { область }\end{array}$ & 20051 & 3,3 & 1161,9 & 2.6 & 57,9 \\
\hline
\end{tabular}

Джерело: сформовано за даними [2-5].

За адміністративно-територіальним поділом селищна рада включає одне селище міського типу та 34 села (рис. 1).

Було з'ясовано, що об'єднані територіальні органи після укрупнення набувають відповідно до закону більше повноважень i отримують більше ресурсів, як до об'єднання, i, відповідно, зобов'язані їх усі виконувати. Тому організаційна структура апарату й виконавчих органів органу місцевого самоврядування повинна відображати ці заявлені повноваження, забезпечуючи інституційно ï ефективне виконання. Кожне повноваження органу місцевого самоврядування має бути закріплено за певним структурним підрозділом чи посадовою особою задля забезпечення його ефективної реалізації. Кожен орган місцевого самоврядування повинен створити структурні підрозділи зі відповідними посадами, які йому необхідні задля функціонування органу.

Варто звернути увагу на той факт, що сьогодні в Україні сформовано в основному необхідне законодавство для регіонального розвитку, яке відповідає встановленим європейським стандартам. Функціонує базовий закон, $€$ державна стратегія регіонального розвитку, яка наближена за своєю структурою до подібних документів країн-членів Європейського Союзу. 


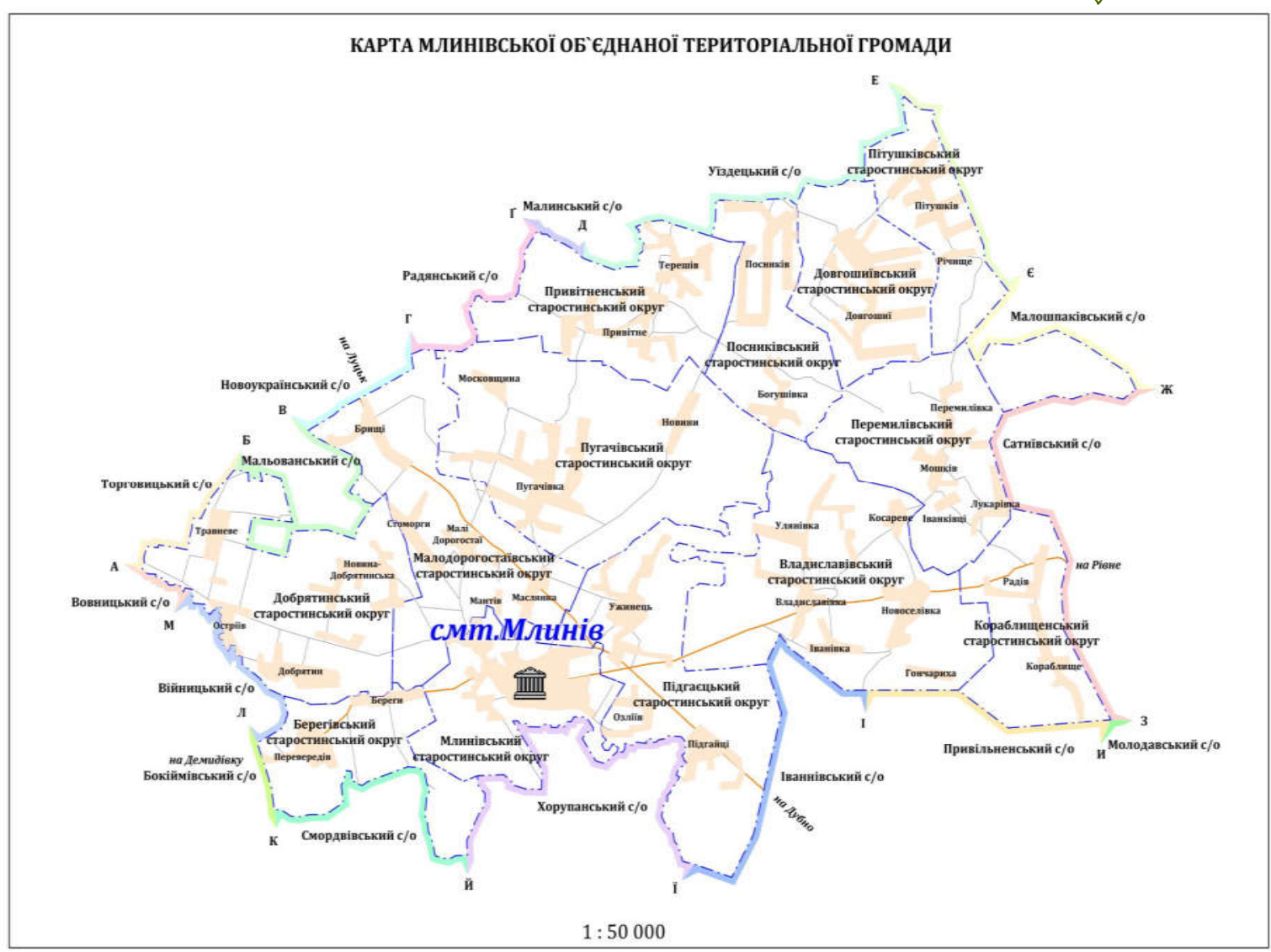

Рис. 1. Карта Млинівської територіальної громади

Джерело: за даними [2-3]

Дослідження фактичної організаційної структури апарату й виконавчих органів сільської (селищної, міської) ради показало, що значний вплив на формування цієї структури має Стратегія розвитку територіальної громади - як основний документ, який визначає пріоритетні напрямки розвитку громади, або програма соціальноекономічного розвитку територіальної громади, або яка покладена в основу підготовки місцевого бюджету у випадку відсутності Стратегії. Стратегія вказує на те, яким чином повинна розвиватися організаційна структура апарату й виконавчих органів місцевої ради в майбутньому, зі перспективою у кілька років. Тож наявність проектних менеджерів в структурі ОТГ забезпечить якісне написання стратегії та втілення її у життя (рис. 2).

У роботі запропонований план стратегічного розвитку Млинівської ОТГ що дозволить реалізувати принципово новий підхід до планування, інвестування й управління економічного розвитку. Основні його принципові особливості - відображення й реалізація інтересів територіальної громади, всеохоплюючий системний підхід до розв'язання проблем розвитку, варіантність та поетапність 
заходів. Кваліфіковано розроблений Стратегічний план розвитку громади розраховують на різний період часу й враховують у ньому заходи коротко-, середньо- та довгострокового інвестування. Він не $\epsilon$ чітко детермінованим і може змінюватися зусиллями постійно діючої робочої групи залежно від зміни обставин, факторів розвитку тощо. Отримані в результаті децентралізації повноваження і фінансові ресурси надали органам місцевого самоврядування більше можливостей для розвитку своїх територій, створення сучасної медичної, освітньої, транспортної, житлово-комунальної інфраструктури. Реалізація стратегії розвитку Млинівської ОТГ дає поштовх до повноцінного розвитку громади, можливість поліпшити життя громадян у кожному населеному пункті (табл. 2).

Таблиця 2

Стратегічна програма 1. «Сталий економічний розвиток» і території впливу»

\begin{tabular}{|l|l|c|}
\hline Завдання & \multicolumn{1}{|c|}{ Назва проєкту } & \multicolumn{1}{|c|}{$\begin{array}{c}\text { Територія } \\
\text { впливу }\end{array}$} \\
\hline \multicolumn{1}{|c|}{2} & \multicolumn{1}{|c|}{2} & \multicolumn{1}{|c|}{3} \\
\hline Hапрям 1.1. Підтримка розвитку малого та середнього бізнесу \\
\hline 1. & $\begin{array}{l}\text { Проведення інвентаризації комунального } \\
\text { майна територіальної громади. Створення } \\
\text { єдиної бази комунального майна громади }\end{array}$ & Млинівська ТГ \\
\hline 2. & $\begin{array}{l}\text { Створення бази інвестиційно-привабливих } \\
\text { об'єктів }\end{array}$ & Млинівська ТГ \\
\hline 3. & $\begin{array}{l}\text { Участь у Проекті Міжнародної організації } \\
\text { праці щодо запровадження місцевих } \\
\text { партнерств зайнятості у Млинівській ОтГ. }\end{array}$ & Млинівська ТГ \\
\hline Напрям 1.2. Розвиток аграрного виробництва і переробки с/г продукції \\
\hline 1. & $\begin{array}{l}\text { Проведення осінніх ярмарок-продажів } \\
\text { сільськогосподарської продукції }\end{array}$ & Млинівська ТГ \\
\hline 2. & $\begin{array}{l}\text { Проведення семінарів з питань розвитку } \\
\text { кооперації. }\end{array}$ & Млинівська ТГ \\
\hline 3. & $\begin{array}{l}\text { Запрошення представників дорадницьких } \\
\text { структур для проведення консультаційних } \\
\text { зустрічей із аграріями }\end{array}$ & Млинівська ТГ \\
\hline Напрям 1.3. Розвиток сільського туризму \\
\hline 1. & $\begin{array}{l}\text { Створення автопарковки й облаштування } \\
\text { території довкола }\end{array}$ & Млинівська ТГ \\
\hline 2. & $\begin{array}{l}\text { Створення екологічної велостежки, територій } \\
\text { розвитку екотуризму, «зеленого» туризму }\end{array}$ & Млинівська ТГ \\
\hline
\end{tabular}


продовження табл. 2

\begin{tabular}{|l|l|l|}
\hline \multicolumn{2}{|l|}{ Напрям 1.4. Розвиток комунального господарства } \\
\hline 1. & $\begin{array}{l}\text { Придбання контейнеровоза й іншої } \\
\text { спеціальної техніки на збір і транспортування } \\
\text { відходів }\end{array}$ & Млинівська ТГ \\
\hline 2. & $\begin{array}{l}\text { Розвиток КЗ «Млинівська дитячо-юнацька } \\
\text { спортивна школа Млинівської селищної ради } \\
\text { Рівненської області» }\end{array}$ & Млинівська ТГ \\
\hline
\end{tabular}

Джерело: сформовано за даними [1-6].

На сьогодні на Рівненщині створено не всі громади від запланованої кількості. Структура новостворених апаратів управління громадами, їх кількісний склад надзвичайно актуальні для тих громад, де незабаром пройде об'єднання. У цій статті здійснено діагностику сучасної організаційної структури органу управління Млинівської ОТГ (рис. 2).

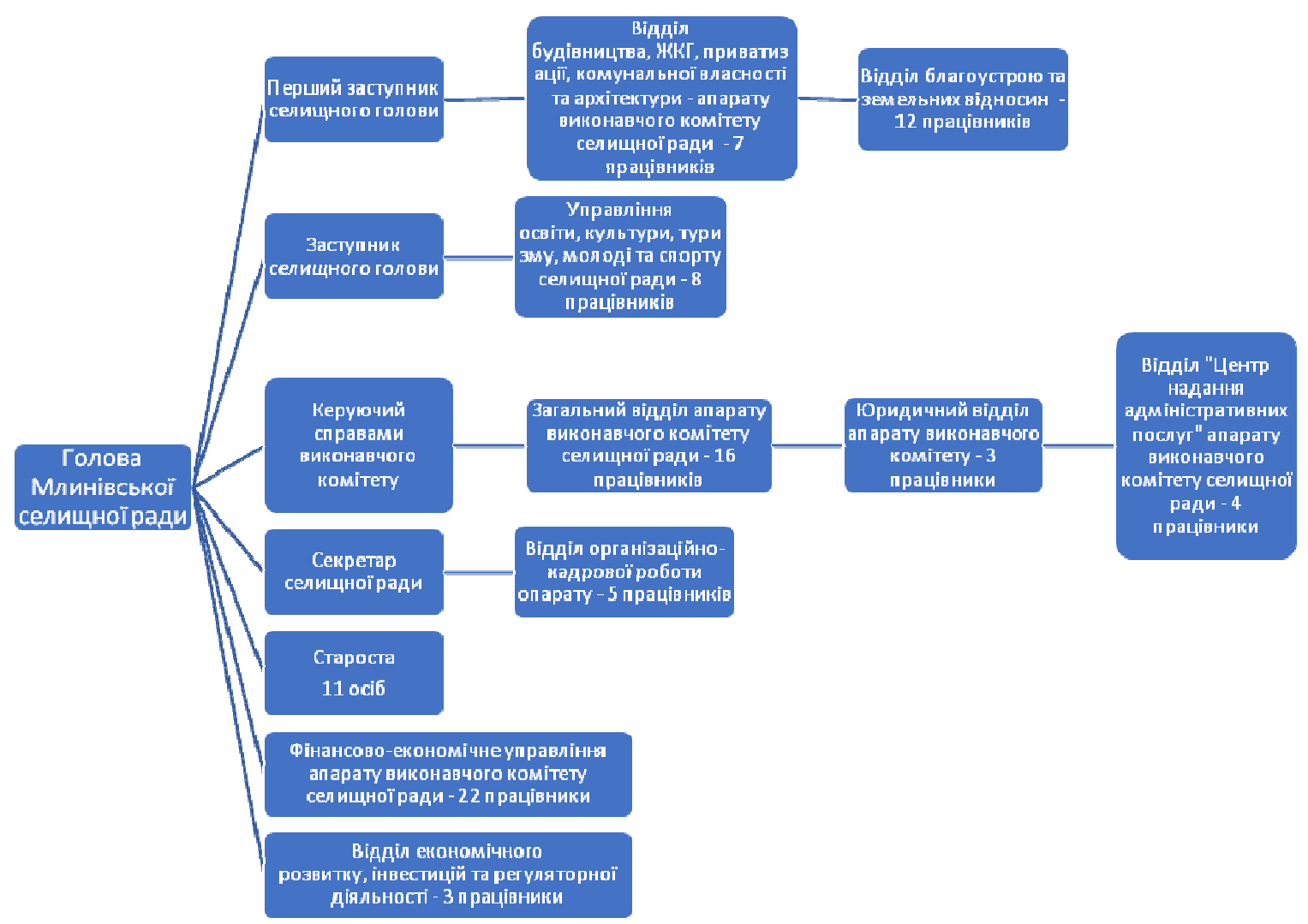

Рис. 2. Структура органу управління Млинівської селищної ради Джерело: узагальнено за даними [2-4]

Насамперед, коли громада зацікавлена в залученні інвестицій, економічному розвитку території, то в її організаційній структурі має бути створено структурний підрозділ з питань економічного розвитку 
й інвестицій [7]. Також, з огляду на деякі завдання Стратегії, зокрема завдання з розвитку туризму, вважаємо за доцільне увести до організаційної структури ОТГ відділ з розвитку туризму. Успіх реалізації й сталості результатів кожного проєкту базується на розумному врахуванні інтересів громади і приватних інтересів. Тому, де це можливо, необхідно правильно поєднувати фінансування із бюджету громади і приватних коштів як додаток щодо підтримки із держбюджету та програм міжнародної співпраці. Стратегія розвитку Млинівської громади передбачає втілення низки проектів, які можуть вплинути на підвищення якості життя населення, сприяти залученню інвестицій у економічний розвиток. Особливий акцент таких проєктів повинен робитися на залучення молоді до суспільновиробничих й підприємницьких процесів сільської місцевості, оскільки молодь $€$ критично важливим фактором у збереженні села.

Реалізація стратегії розвитку Млинівської ОТГ надасть поштовх до повноцінного соціо-еколого-економічного розвитку громади, можливість поліпшити життя у кожному населеному пункті.

Висновки. Сьогодні в Україні сформовано необхідне законодавство для регіонального розвитку, яке в цілому відповідає кращим європейським стандартам. Є базовий закон, державна стратегія регіонального розвитку, яка дуже подібна за структурою до діючих документів Європейського Союзу. На прикладі Млинівської ОТГ запропоновано елементи Стратегії розвитку територіальної громади, як основного документа, який визначає пріоритетні напрямки розвитку громади. Запропоновано удосконалити чинну організаційну структуру органу управління Млинівської ОТГ, адже пріоритетні напрями розвитку територіальної громади неможливо зреалізувати без інституційної спроможності органу - наявності працівників відповідної кваліфікації й структурних підрозділів, відповідальних за реалізацію задекларованих пріоритетів. Стратегія орієнтує на те, яким чином має трансформуватися (адаптуватися) організаційна структура апарату й виконавчих органів місцевої ради в майбутньому. Тому наявність проєктних менеджерів у цій структурі забезпечить якісне написання стратегії і беззаперечне втілення ії в життя. Як підсумок можна сказати, що нині Млинівська ОТГ $€$ сучасною громадою із великим потенціалом та із чітким баченням власного розвитку. Розробка такої стратегії визначає принципово новий підхід до планування й управління економічним розвитком території, формування ії позитивного іміджу. Основні принципові особливості його - це відображення й реалізація інтересів територіальної громади, всебічний й системний підхід до 
розв'язання екологічних, політичних, фінансових проблем розвитку, варіантність та поетапність. Кваліфіковано розроблений Стратегічний план розвитку громади має охоплювати інвестиційні заходи з їх дорожньою картою. Він не є чітко детермінованим і може змінюватися робочою групою залежно від зміни обставин, факторів розвитку тощо. Отримані в результаті децентралізації повноваження і ресурси надали органам місцевого самоврядування більше можливостей для розвитку своїх територій, створення сучасної медичної, житлово-комунальної, освітньої, транспортної інфраструктури.

Важливим напрямом діяльності територіальних громад задля забезпечення інвестицій $є$ участь у проєктах міжнародної технічної допомоги, у тому числі Європейського Союзу. Це $\epsilon$ ефективним шляхом у наданні фінансових ресурсів й технічної допомоги, забезпеченні управлінського потенціалу і технічних навичок для реалізації стратегії. Успішний досвід інших регіонів і держав здатний прискорити реалізацію проектів і сприяти отриманню максимальної віддачі від них.

1.Управління розвитком об'єднаних територіальних громад на засадах громадської участі : навч. посіб. / О. В. Берданова, В. М. Вакуленко, Н. М. Гринчук, В. С. Колтун, В. С. Куйбіда, А. Ф. Ткачук. К., 2017. 129 с. 2. Децентралізація влади. Реформа децентралізації влади. URL: decentralization.gov.ua. (дата звернення: 07.01.2021). 3. Концепція реформування місцевого самоврядування та територіальної організації влади в Україні : схвалено розпорядженням Кабінету Міністрів України від 1.04.2014 p., № 333-p. URL: http://zakon5.rada.gov.ua/laws/show/333-2014-\%D1\%80. (дата звернення: 07.01.2021). 4. Васильченко Г., Парасюк І., Єременко Н. Планування розвитку територіальних громад : навч. посіб. для посадових осіб місцевого самоврядування / Г. Васильченко, І. Парасюк, Н. Єременко / Асоціація міст України. К., ТОВ «ПІДПРИЕМСТВО «ВІ ЕН ЕЙ», 2015. 256 с. 5. Методичні рекомендації щодо формування регіональних стратегій розвитку : затв. Наказ Міністерства економіки та $з$ питань європейської інтеграції України від 29.07.2002 р., № 224. URL: http://zakon.nau.ua/doc/7uicN1022.322.0 (дата звернення: 07.01.2021). 6. Євроінтеграція на стику влад: чи є успіхи України у впровадженні реформ. Громадська синергія. URL: http://www.civic-synergy.org.ua (дата звернення: 07.01.2021). 7. Підходи до формування ефективних організаційних структур для об'єднаних територіальних громад. URL: http://ucmc.org.ua/uk/praktichnij-posibnikefektivni-organizatsijni-strukturi-dlya-otg-usaid-dobre (дата звернення: 07.01.2021).

\section{REFERENCES:}

1. Upravlinnia rozvytkom obiednanykh terytorialnykh hromad na zasadakh hromadskoi uchasti : navch. posib. / O. V. Berdanova, V. M. Vakulenko, N. M. Hrynchuk, V. S. Koltun, V. S. Kuibida, A. F. Tkachuk. K., 2017. 129 s. 2. Detsentralizatsiia vlady. Reforma detsentralizatsii vlady. URL: decentralization.gov.ua (data zvernennia: 
07.01.2021). 3. Kontseptsiia reformuvannia mistsevoho samovriaduvannia ta terytorialnoi orhanizatsii vlady $v$ Ukraini : skhvaleno rozporiadzhenniam Kabinetu Ministriv Ukrainy vid 1.04.2014 r., № 333-r. URL: http://zakon5.rada.gov.ua/laws/show/333-2014-\%D1\%80. (data zvernennia: 07.01.2021). 4. Vasylchenko H., Parasiuk I., Yeremenko N. Planuvannia rozvytku terytorialnykh hromad : navch. posib. dlia posadovykh osib mistsevoho samovriaduvannia / H. Vasylchenko, I. Parasiuk, N. Yeremenko / Asotsiatsiia mist Ukrainy. K., TOV «PIDPRYleMSTVO «VI EN El», 2015. 256 s. 5. Metodychni rekomendatsii shchodo formuvannia rehionalnykh stratehii rozvytku : zatv. Nakaz Ministerstva ekonomiky ta z pytan yevropeiskoi intehratsii Ukrainy vid 29.07.2002 p., № 224. URL: http://zakon.nau.ua/doc/7uicN1022.322.0 (data zvernennia: 07.01.2021). 6. Yevrointehratsiia na styku vlad: chy ye uspikhy Ukrainy u vprovadzhenni reform. Hromadska synerhiia. URL: http://www.civic-synergy.org.ua (data zvernennia: 07.01.2021). 7. Pidkhody do formuvannia efektyvnykh orhanizatsiinykh struktur dlia obiednanykh terytorialnykh hromad. URL: http://ucmc.org.ua/uk/praktichnij-posibnikefektivni-organizatsijni-strukturi-dlya-otg-usaid-dobre (data zvernennia: 07.01.2021).

Yakymchuk A. Yu. ${ }^{[1 ; 0 R C I D ~ I D: 0000-0002-5038-5215], ~}$ Doctor of Economics, Professor of Department of Public Administration, Documentation and Informational Activity

${ }^{1}$ National University of Water and Environmental Engineering, Rivne

\section{STRATEGIC FUNDAMENTALS OF INVESTMENT SUPPORT OF TERRITORIAL COMMUNITIES}

In the process of decentralization reform, united territorial communities have been entering a new stage of their development. They have received the authority, investment resources, are responsible to their residents for the formation of a comfortable and safe living environment. This requires predictable and motivated community development. Based on the results of socio-economic analysis, SWOT-analysis is necessary now basic competitive strategy for the development of local communities, taking into account the investment component, which would provide the formation of competitive advantages of the community by minimizing the impact on the development of weaknesses and in the world. At the same time, the community should make the most of its strengths. Today in Ukraine the normative-legislative basis for regional development has been formed, which as a whole corresponds to the best European standards. Currently, a state strategy for regional development has been developed, which has been very closed in structure to similar documents of the European Union member states. Based on the study on the example of Mlynivska OTG, a plan of strategic development of Mlynivska OTG has been proposed which will allow to implement a fundamentally new approach to planning, investing and managing economic development. The differences of such a plan are the 
reflection and realization of the interests of the territorial community, a systematic approach to solving development problems. The strategic community development plan includes measures for short-, medium- and long-term investment. As a result of the decentralization reform, local communities have gained better opportunities for the development of their territories, the creation of modern medical, educational, transport, housing and communal infrastructure, as well as prospects to improve the lives of citizens in each locality.

Keywords: territorial community; state; investments; natural resources; development strategy; sustainable development.

Якимчук А. Ю. [1; ORCID ID: 0000-0002-5038-5215], д.э.н., профессор

${ }^{1}$ Национальный университет водного хозяйства и природопользования, г. Ровно

\section{СТРАТЕГИЧЕСКИЕ ОСНОВЫ ИНВЕСТИЦИОННОГО ОБЕСПЕЧЕНИЯ ТЕРРИТОРИАЛЬНЫХ ОБЩИН}

В процессе децентрализационной реформы объединенные территориальные общины сегодня вступают в новый этап своего развития. Они получили полномочия, инвестиционные ресурсы, ответственны перед своими жителями за формирование комфортной и безопасной среды проживания. Для этого нужен прогнозируемое и мотивированное развитие общин. Основываясь на результатах социально-экономического анализа, SWOT-анализа, необходима сейчас базовая динамическая конкурентная стратегия развития территориальных общин с учетом инвестиционной составляющей, которая бы предусматривала формирование конкурентных преимуществ общины путем минимизации влияния на развитие слабых сторон с помощью возможностей, которые возникают в нашей стране и в мире. При этом общество должно максимально использовать свои сильные стороны. Сегодня В Украине сформирована хорошая нормативнозаконодательная база для регионального развития, что В целом соответствует лучшим европейским стандартам. В настоящее время разработаны государственная стратегия регионального развития, которая очень близка по структуре к подобным документам стран-членов Европейского Союза. На основе проведенного исследования на примере Млыновской ОТГ, предложен план стратегического развития Млыновской ОТГ что позволит реализовать принципиально новый подход к планированию, инвестированию и управлению экономического развития. Различия такого плана заключаются в отображении и реализации 
интересов территориальной общины, системный подход к решению проблем развития. Стратегический план развития общины содержит мероприятия по кратко-, средне- и долгосрочного инвестированию. В результате реформы децентрализации местные общины получили новые возможности по развитию своих территорий, созданию современной медицинской, образовательной, транспортной, жилищно-коммунальной инфраструктуры, а также перспективы улучшить жизнь граждан в каждом населенном пункте.

Ключевые слова: территориальная община, государство, инвестиции, природные ресурсы, стратегия развития, устойчивое развитие.

Отримано: 10 березня $2021 \mathrm{p.}$ Прорецензовано: 15 березня 2021 р. Прийнято до друку: 26 березня 2021 р. 